Article

\title{
Comparing Medicinal Uses of Cochlospermaceae throughout Its Geographic Range with Insights from Molecular Phylogenetics
}

\author{
Susannah B. Johnson-Fulton ${ }^{1, *}$ and Linda E. Watson ${ }^{2}$ \\ 1 Department of Biology, Shasta College, Redding, CA 96003, USA \\ 2 Department of Plant Biology, Ecology, and Evolution, Oklahoma State University, Stillwater, OK 74078, USA; \\ linda.watson10@okstate.edu \\ * Correspondence: sfulton@shastacollege.edu
}

Received: 13 September 2018; Accepted: 8 November 2018; Published: 15 November 2018

\begin{abstract}
Species of the Cochlospermaceae, a small mostly pantropical plant family, were evaluated at a continental scale for medicinal uses in traditional medicine. This ethnobotanical information was placed in a phylogenetic framework to make informed predictions in the search for new medicines and bioactive compounds. Medicinal plant-use data were mapped onto a molecular phylogeny based on DNA sequences of nuclear and chloroplast markers. Associations of medicinal uses among closely related species occurring in different geographic regions and among diverse cultures were evaluated. The most common medicinal uses for these species are those used to treat skin ailments, gastro-intestinal problems, malaria, and liver issues. The plant species with the most numerous uses is Cochlospermum tinctorium, which occurs primarily in West Africa. Closely related species being used by cultural groups in different geographic regions to treat the same illnesses suggests the presence of bioactive compounds with potential biomedical value, since they may represent independent discoveries of similar medicinally-active compounds. This leads to the speculation that those closely related species not currently being used to treat these ailments may also contain identical or similar medicinally-active compounds and are worthy of laboratory investigations.
\end{abstract}

Keywords: Cochlospermaceae; Cochlospermum; Amoreuxia; medicinal plants; comparative ethnobotany; phylogenetics; molecular systematics; biogeography; culture; pharmacology

\section{Introduction}

Humans, like much of life on Earth, depend almost entirely on plants for survival [1-3]. Most of our food comes from plants both directly and indirectly. Much of our clothing and building materials consist of plant material. And although most drugs in western medicine are produced in the laboratory, these synthesized compounds usually mimic bioactive compounds first discovered in the plants in which they naturally occur [2,4,5]. According to the World Health Organization (WHO), approximately $80 \%$ of developing countries still depend on traditional folk medicines, $85 \%$ of which are plant extracts with the other $15 \%$ being mineral, fungal, and animal based. Thus, with over 250,000 species of angiosperms alone, and a plethora of plant use knowledge available, the potential for making many new discoveries, making new connections, and finding new medicinal plants and medicinally-active compounds for drug development is enormous. With the effects of global warming, the increased loss of the world's biodiversity, and the disappearance of unique human cultures, it has become even more important to discover and conserve Earth's species, to document and conserve cultural histories, traditions, and languages, and to search for new medicines and new drought tolerant foods [6-9].

Comparing the medicinal uses of closely related plant species throughout their geographic ranges among different cultural groups can offer a new perspective into the search for effective 
botanical medicines and other plant species with economic value [10]. Cochlospermaceae Planch. is a small, ethnobotanically important pantropical plant family with species distributed in west and central Africa, India, Southeast Asia, Northern Australia, Central and South America, the West Indies, Mexico, and Southwestern United States (Figure 1). It is composed of two genera, Amoreuxia DC., four herbaceous species, and Cochlospermum Kunth, 12 woody species (Figure 2). Of its 16 species, 12 are known to be used by many cultures on different continents [11-19]. The widespread distribution of its species combined with its rich ethnobotanical use makes Cochlospermaceae an ideal family to explore any tendencies for closely related species to be used in similar ways by people of diverse cultural groups. If, for example, closely related species are used in similar ways by distantly related cultures, then those species may, in fact, provide more effective medicines because they represent independent discoveries of similar medicinally-active compounds.

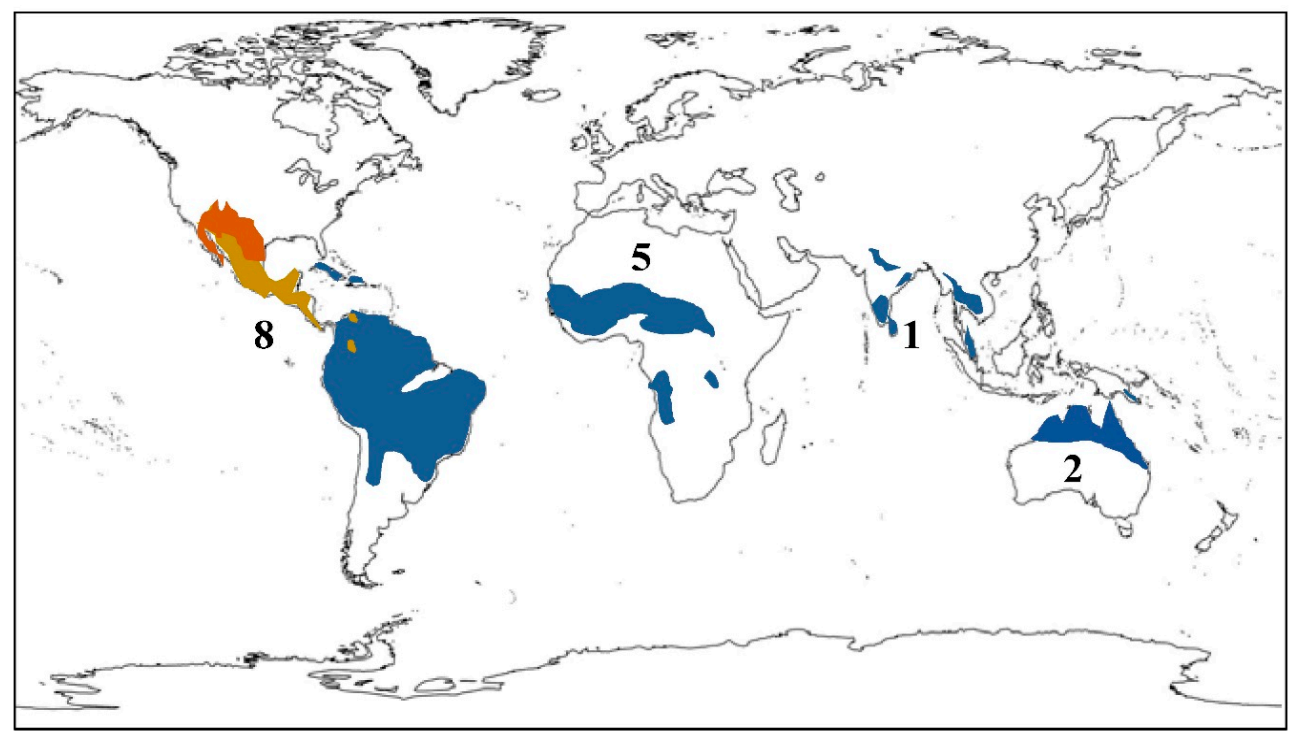

Figure 1. Distribution of the two genera of Cochlospermaceae. Blue $=$ Cochlospermum; Orange = Amoreuxia; Yellow = overlapping ranges of the two genera. Numbers indicate the numbers of species in different geographic regions. 8-the Americas; 5-Africa; 1-Asia; 2-Australia.

Four major strategies are generally used in the search for medicinally-active plants: (1) random approach—randomly selecting plants to sample in a particular area; (2) phylogenetic approach — choosing species that are closely related to other species with known medicinally-active compounds; (3) ecological approach - selecting plants that live in certain habitats or that exhibit specific characteristics, such as anti-herbivory compounds; and (4) ethnobotanical approach—choosing plants that are used by local people to treat illness [2]. The ethnobotanical approach is currently known to be the most successful of the major strategies $[10,20]$. Here we have combined both the phylogenetic and ethnobotanical approaches by choosing a geographically-widespread plant family, reconstructing a molecular phylogeny for the family, mapping ethnobotanical data onto the resulting phylogeny, and evaluating correlations between the evolutionary relatedness of the species and their ethnobotanical uses by different cultural groups who live in different geographic regions. Studies such as this that utilize phylogenetic patterns of medicinal properties within plant lineages are few [10,21-29]. Saslis-Lagoudakis et al. [10] concluded that phylogenetic cross-cultural comparisons can focus screening efforts on the closest relatives of medicinal plants already in use as traditional medicines.

Few comparative ethnobotanical studies, in general, have been conducted, and those that have been conducted usually compare the total use of plants among different cultural groups rather than examining the uses of a single plant lineage across its geographic range [10,30-32]. This research focuses on a single plant family with a widespread distribution and compares how diverse ethnic groups from different geographic regions use the closely related species medicinally. 


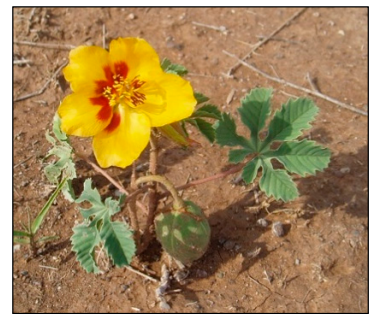

(a)

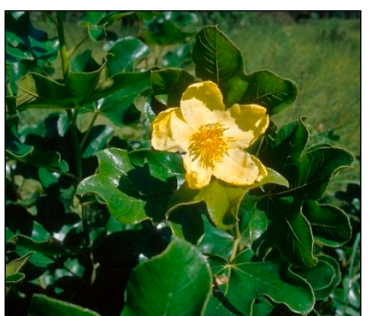

(b)

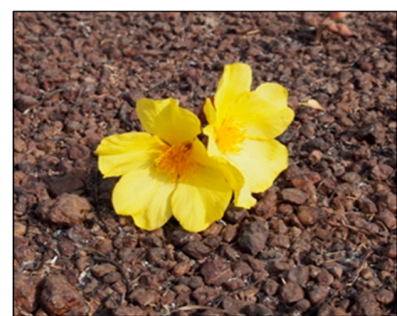

(c)

Figure 2. Examples of Cochlospermaceae: (a) herbaceous Amoreuxia wrightii flowering and fruiting in Nuevo Leon, Mexico; (b) Cochlospermum planchonii (sub-shrub) exhibiting characteristic large yellow flowers and palmately lobed leaves in Senegal, West Africa; (c) Cochlospermum tinctorium (sub-shrub) blooming straight from the ground after a savannah fire in Senegal, West Africa.

Through the course of this study, we aimed to: (1) compare how people of different geographic regions use the species of Cochlospermaceae as medicines; (2) determine which species are more commonly used; (3) distinguish which medicinal uses are most common among the different plant species and between different geographic regions; (4) identify which species have received the most attention in pharmacological research, and which are candidates that lack pharmacological research attention; and (5) map ethnomedicinal data onto a molecular phylogeny and evaluate correlations between the evolutionary relatedness of the plant species and the medicinal uses in different geographic regions.

\section{Materials and Methods}

Literature related to the medicinal ethnobotany of the geographic regions where species of Cochlospermaceae grow was examined, as well as all published pharmacological research conducted on its species. Some plant use data was gathered in the field for Amoreuxia wrightii A. Gray in Yucatan, Mexico (2006), Cochlospermum orinocense (Kunth) Steud. in the Peruvian Amazon (2005), and C. planchonii Hook.f. ex Planch. and C. tinctorium Perr. in the region of Kedougou, Senegal (2002 \& 2017). Field data were gathered through formal and informal interviews following the interview methods described by Alexiades [33] and Martin [34].

Medicinal uses were divided into the following categories: Gastro-intestinal, Respiratory, Kidney, Urinary Tract, Female Health, Male Health, Muscular/Skeletal, Infections/Fevers, Vascular/Blood, Hepatitis/Jaundice, Skin, Neurological, Pain, Snake Bites, Eyes, Malaria, and Unspecific. Selected medicinal uses of Cochlospermaceae were coded as character states and traced onto the previously published majority rule consensus tree resulting from a Bayesian inference analysis of the combined nuclear (ITS (internal transcribed spacer)) and chloroplast ( $\operatorname{trn} G$ and $\operatorname{trnL}-F$ ) DNA matrix by the authors of this paper, Johnson-Fulton and Watson [35], using MacClade 4 [36]. Exploration of character trait evolution was conducted using ACCTRAN optimization assuming Fitch parsimony, equal weighting of all characters, equal transitioning probability among all states, and characters as unordered.

\section{Results and Discussion}

Of the 16 species of Cochlospermaceae examined in this study, nine have documented medicinal uses. Table 1 lists the medicinal use, general locality, and plant parts used. Of the different uses, many are shared by two or more plant species throughout the geographic range of the plant family. Of the nine ethnomedicinal species of Cochlospermaceae, we found that Cochlospermum tinctorium, a subshrub from Africa that usually flowers at ground level after fire (Figure 2), and C. religiosum (L.) Alston, a tree originating in India, far surpass all other species in number of medicinal uses with C. inctorium having 54 medicinal uses and C. religiosum with 52 (Figure 3). The next most highly used species are C. vitifolium Spreng. (19 uses), a tree with a widespread range in the Americas, and C. regium Pilg. (16 uses), a subshrub from South America (Figures 1 and 3). 
Table 1. Major medicinal uses of species of Cochlospermaceae, including general geographic regions where uses occur, plant parts used, and references.

\begin{tabular}{|c|c|c|c|}
\hline Plant Species & Geographic Regions & Plant Parts & Medicinal Uses/Ailments Treated \\
\hline Amoreuxia wrightii A. Gray & Mexico & Leaves & Headache \\
\hline \multirow{10}{*}{$\begin{array}{l}\text { Cochlospermum vitifolium } \\
\text { Spreng. }\end{array}$} & Mexico & Bark & Snakebites, diarrhea, skin rashes, hepatitis, jaundice, liver issues, hypertension, high blood pressure, hyperglycemia, diabetes, asthma, cleanse vagina, veterinary \\
\hline & Panama & Bark & Liver issues, kidney issues \\
\hline & Mexico, Guatemala & Wood, leaves & Chest issues, jaundice, liver issues, kidney issues, hasten childbirth \\
\hline & Costa Rica & Wood & Jaundice \\
\hline & Mexico, Cuba & Leaves & Ulcers \\
\hline & Mexico & Flowers & Chest issues, hepatitis \\
\hline & Mexico, Cuba & Root & Stimulate menstruation, abscesses, intestinal issues \\
\hline & \multirow{2}{*}{ Panama } & Fruit & Blood circulation \\
\hline & & Not specified & Eating disorders, anti-hypertensive \\
\hline & {$[11,14,37-45]$} & & \\
\hline \multirow{4}{*}{ Cochlospermum regium Pilg. } & \multirow{3}{*}{ Brazil } & Roots & $\begin{array}{l}\text { Inflammation of the intestine, uterus, and ovaries; skin problems (boils, pimples, dermatitis, and blotchy skin), arthritis and rheumatism, acne, infections of the } \\
\text { reproductive and urinary systems }\end{array}$ \\
\hline & & Bark & Rheumatoid arthritis, and in a compress to help heal abscesses \\
\hline & & Not specified & $\begin{array}{l}\text { Headaches, internal cleansing agent (removing wastes and toxins), heal wounds, cleanse blood, laxative, internal pains, leucorrhea (abnormal vaginal discharge), } \\
\text { inflammation/infection of prostate, gastritis, ulcers }\end{array}$ \\
\hline & {$[11,46-52]$} & & \\
\hline \multirow{3}{*}{$\begin{array}{l}\text { Cochlospermum orinocense } \\
\text { (Kunth) Steud. }\end{array}$} & \multirow{2}{*}{ Amazon } & Bark & Fevers \\
\hline & & Not specified & Bruises, wounds, promotes formation of scar tissue \\
\hline & {$[53,54]$} & & \\
\hline \multirow{7}{*}{$\begin{array}{l}\text { Cochlospermum planchonii } \\
\text { Hook.f. ex Planch. }\end{array}$} & Burkina Faso & Roots & Malaria, hepatitis, jaundice, liver issues, constipation \\
\hline & Ivory Coast & Roots & Fevers, malaria \\
\hline & Nigeria & Roots & Jaundice, fevers, and malaria \\
\hline & Niger & Roots & Jaundice, malaria, fevers, lactation issues \\
\hline & Benin & Leaves & Edema \\
\hline & West Africa & Not specified & Stomach troubles, burns, indigestion, leprosy, jaundice, testicular inflammation, and urethral discharges \\
\hline & {$[11,55-63]$} & & \\
\hline \multirow[t]{2}{*}{$\begin{array}{l}\text { Cochlospermum tinctorium } \\
\text { Perr. }\end{array}$} & $\begin{array}{l}\text { West Africa, including: } \\
\text { Ivory Coast, Ghana, } \\
\text { Cameroon, Nigeria, } \\
\text { Gambia, Guinea-Bissau, } \\
\text { Guinea, Togo, and } \\
\text { Senegal, }\end{array}$ & Roots & Jaundice, liver diseases, yellow fever, and malaria \\
\hline & West Africa & Not specified & $\begin{array}{l}\text { Epilepsy, schistosomiasis, leprosy and other skin infections, burns, edema, urethral discharge, menstrual cramps, testicular inflammation, pneumonia and other } \\
\text { lung infections, conjunctivitis, indigestion, stomachache, diarrhea, rickets, intestinal worms, and beriberi, stimulate blood flow in the uterus and pelvic region and } \\
\text { aid in childbirth }\end{array}$ \\
\hline
\end{tabular}


Table 1. Cont

\begin{tabular}{|c|c|c|c|}
\hline Plant Species & Geographic Regions & Plant Parts & Medicinal Uses/Ailments Treated \\
\hline & \multirow{3}{*}{ Mali } & Roots & $\begin{array}{l}\text { Urinary issues, schistosomiasis, gastrointestinal problems, such as ulcers, stomachaches, constipation, and flatulence, abdominal pains, wounds, hemorrhoids, } \\
\text { intestinal worms, schistosomiasis, and hepatitis, snakebites }\end{array}$ \\
\hline & & Leaves & Malaria, ulcers, and flatulence \\
\hline & & Flowers & Constipation \\
\hline & Senegal & Roots & $\begin{array}{l}\text { Rickets, colic, indigestion, ascite, beriberi, hemorrhoids, testicular inflammation, schistosomiasis, syphilis, bronchitis, convulsions, epilepsy, fever, imflammation } \\
\text { of lymmp nodes, measles, malaria, blepharitis (inflammation of eyelid), gonorrhea, boils, worms }\end{array}$ \\
\hline & Togo & Root & Painful menstruation, rectal prolapse, jaundice \\
\hline \multirow{13}{*}{ Cochlospermum tinctorium } & \multirow{2}{*}{ Benin } & Root & Jaundice, inner hemorrhaging, headache \\
\hline & & Whole plant & Weakness \\
\hline & \multirow{4}{*}{ Nigeria } & Root & Promote general body health \\
\hline & & Root, stem & Veterinary medicine \\
\hline & & Fruit & Snakebites \\
\hline & & Seed (oil) & Leprosy \\
\hline & Niger & Roots & Jaundice \\
\hline & Ghana & Roots & $\begin{array}{l}\text { Bronchial problems (pneumonia, lung inflammation), epileptic convulsions, eye issues (conjunctivitis, trachoma, sore eyes), fevers, hernias, chest pain, leprosy } \\
\text { absence of menstruation, female sterility, hemorrhoids, sprains, burns, bruises, stomachaches, indigestion, inflammation, venereal diseases, snakebites, bleeding } \\
\text { diarrhea, rheumatic muscle and back pain }\end{array}$ \\
\hline & Burkina Faso & Root & Malaria \\
\hline & \multirow{3}{*}{ Ivory Coast } & Root & $\begin{array}{l}\text { Inflammation of the testes, schistosomiasis, jaundice, fevers, epilepsy, pneumonia, chest pain, bronchial problems (pneumonia), conjunctivitis, indigestion, } \\
\text { stomach pain, snakebites, skin diseases }\end{array}$ \\
\hline & & Leaves & Abscesses and boils \\
\hline & & Stems, roots & Urinary and genital pain and disorders, kidney pain, chest pain \\
\hline & {$[15,56,63-74]$} & & \\
\hline \multirow{2}{*}{$\begin{array}{l}\text { Cochlospermum angolense } \\
\text { Welw. }\end{array}$} & Angola & Bark, roots & $\begin{array}{l}\text { Protect and heal liver, jaundice, hepatitis, prophylaxis and treatment for malaria, stomach, liver, gallbladder, spleen, and urinary tract, and also used externally as } \\
\text { a wash for skin problems, such as herpes and open sores }\end{array}$ \\
\hline & {$[11,75,76]$} & & \\
\hline \multirow{5}{*}{$\begin{array}{l}\text { Cochlospermum religiosum } \\
\text { (L.) Alston }\end{array}$} & \multirow[t]{4}{*}{ India } & Not specified & $\begin{array}{l}\text { Dry cough, tuberculosis, bronchitis, laryngitis, colds, sneezing, mucus inflammation in the nose, throat, and sinuses, varicose veins, malaria, weakness, fever, } \\
\text { headache, earache, hard of hearing, optic inflammation, and inflammation of the stomach, liver, kidney, and urinary tract. Other uses include expelling phlegm } \\
\text { from the lungs, dissolving bladder and kidney stones, removing warts, relieving and moisturizing sore, irritated, and/or congested eyes, and enhancing } \\
\text { ejaculation while controlling excessive and/or involuntary emissions, stop or slow bleeding by contracting tissues and/or blood vessels, excessive menstrual } \\
\text { bleeding, blood in the urine, bleeding hemorrhoids, lower intestinal bleeding, and vomiting blood. Aphrodisiacs, cerebral tonics (relaxes and soothes anxiety and } \\
\text { nervous twitches), astringents, diuretics, general anti-inflammatories, internal cooling agents, and assists with opium addictions }\end{array}$ \\
\hline & & Leaves, flowers & Stimulant \\
\hline & & Whole plant & Coughs \\
\hline & & Gum & $\begin{array}{l}\text { Pain reliever, sedative, and laxative, and is thought to be thermogenic. It is also used to treat cough, diarrhea, dysentery, pharyngitis, gonorrhoea, syphilis, } \\
\text { trachoma, and stomach and urinary tract disorders, protection from heat strokes }\end{array}$ \\
\hline & {$[11,16,18,77-80]$} & & \\
\hline \multirow{3}{*}{$\begin{array}{l}\text { Cochlospermum } \\
\text { fraseri Planch. }\end{array}$} & \multirow{2}{*}{ Australia } & Root & Treat sores, boils, and cuts \\
\hline & & Leaves, bark, flowers & Treat fevers \\
\hline & {$[81,82]$} & & \\
\hline
\end{tabular}




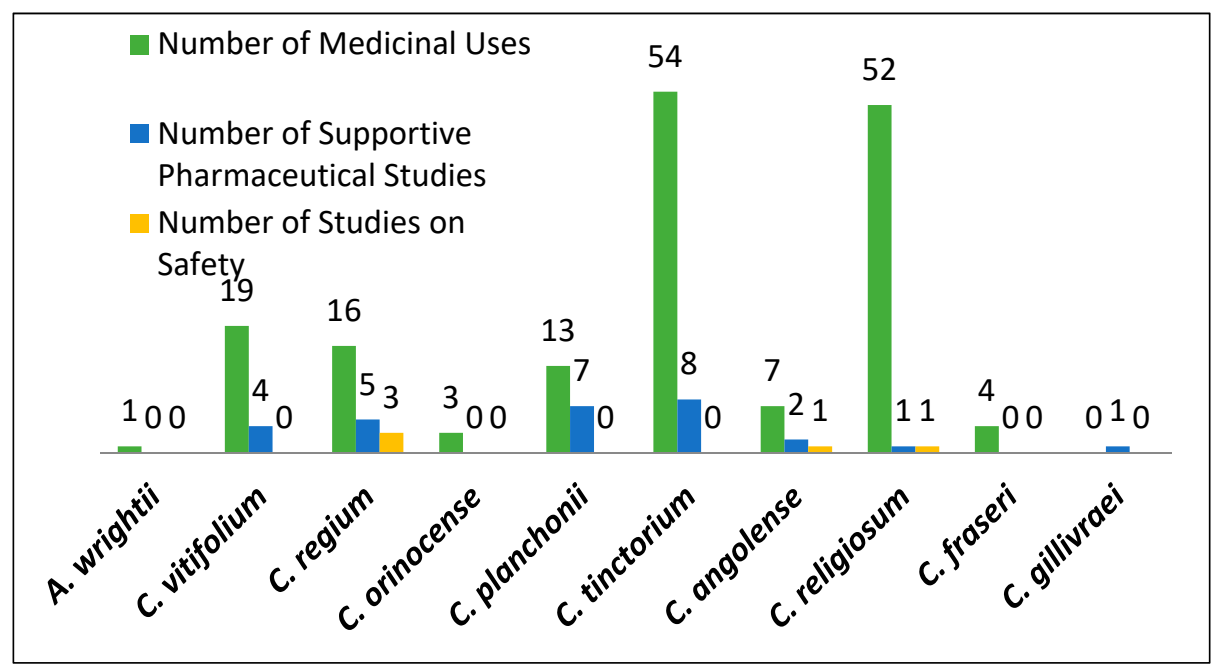

Figure 3. Numbers above bars indicate medicinal uses per species and pharmacological studies that support medicinal activity and safety.

Of the many documented uses, a high number fall into the categories of gastro-intestinal, skin, and female health afflictions, with many of the gastro-intestinal uses occurring in Africa (Figure 4). The highest number of species (eight species) are used to treat skin related issues, such as abscesses, boils, infections, burns, bruises, and cuts in all four major geographic regions, with many of the uses occurring in Africa and the Americas: C. tinctorium, C. planchonii, and C. angolense in Africa, C. vitifolium, C. regium, and C. orinocense in the Americas, C. religiosum in India, and C. fraseri Planch. in Australia (Figures 4-6). Six different species are used to treat gastro-intestinal issues, such as indigestion, ulcers, intestinal parasites, and diarrhea in three major geographic regions: Cochlospermum tinctorium, C. planchonii, and C. angolense Welw. in Africa, C. vitifolium and C. regium in the Americas, and C. religiosum in India (Figures 4-6). The female affliction category has the same number of uses in Africa as in the Americas (Figure 4). Five species are used to treat female afflictions, such as uterine and ovarian infections and menstruation and childbirth issues in three major geographic regions: Cochlospermum tinctorium and C. planchonii in Africa, C. vitifolium and C. regium in the Americas, and C. religiosum in India (Figures 4-6).

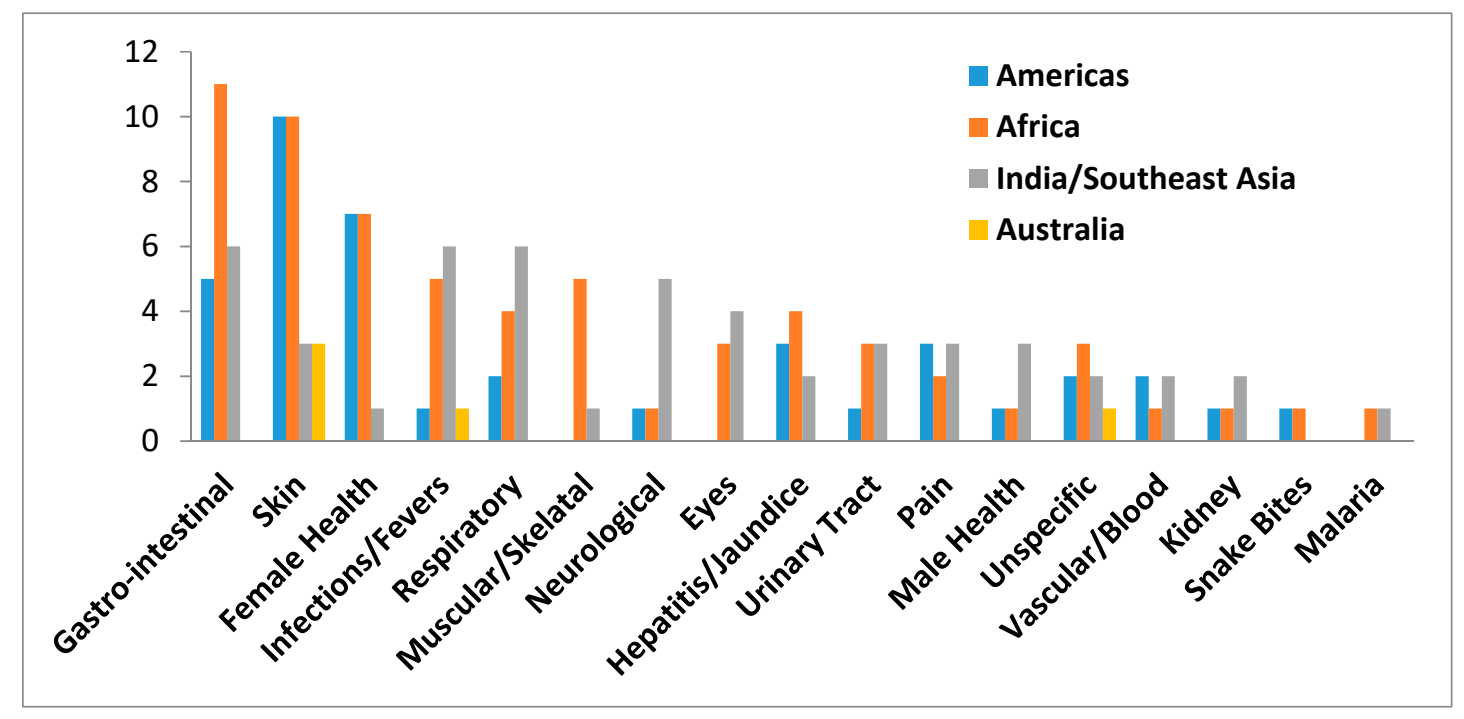

Figure 4. Number of different types of uses ( $y$-axis) per major category of medicinal use ( $x$-axis) for species of Cochlospermaceae in the Americas, Africa, India/Southeast Asia, and Australia. 


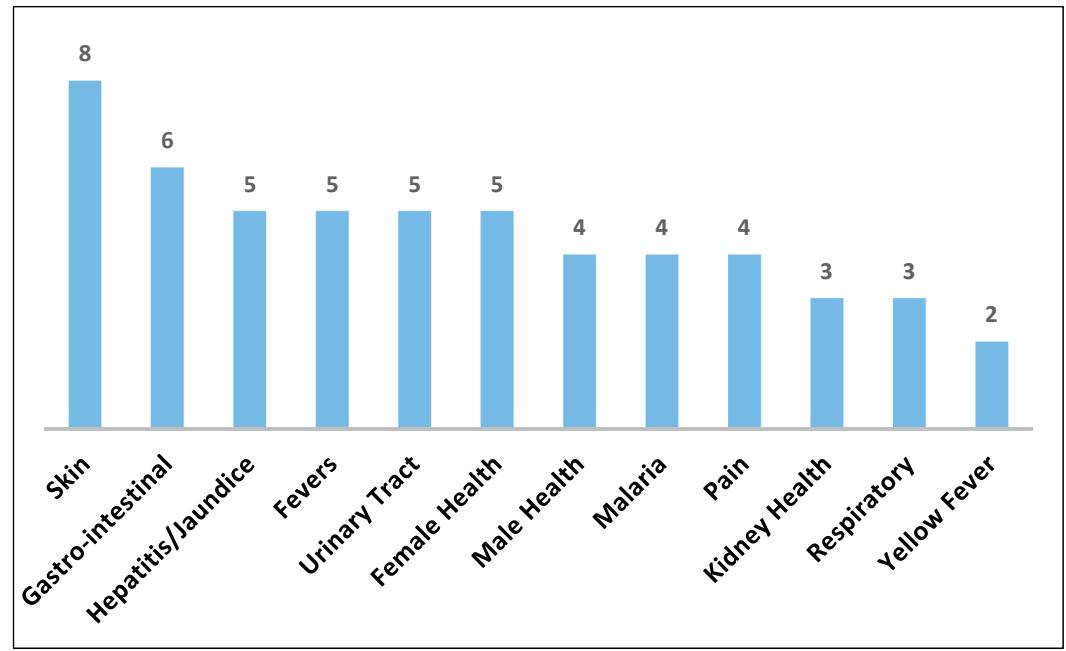

Figure 5. Number of species of Cochlospermaceae (indicated above bar) used for selected medicinal uses.

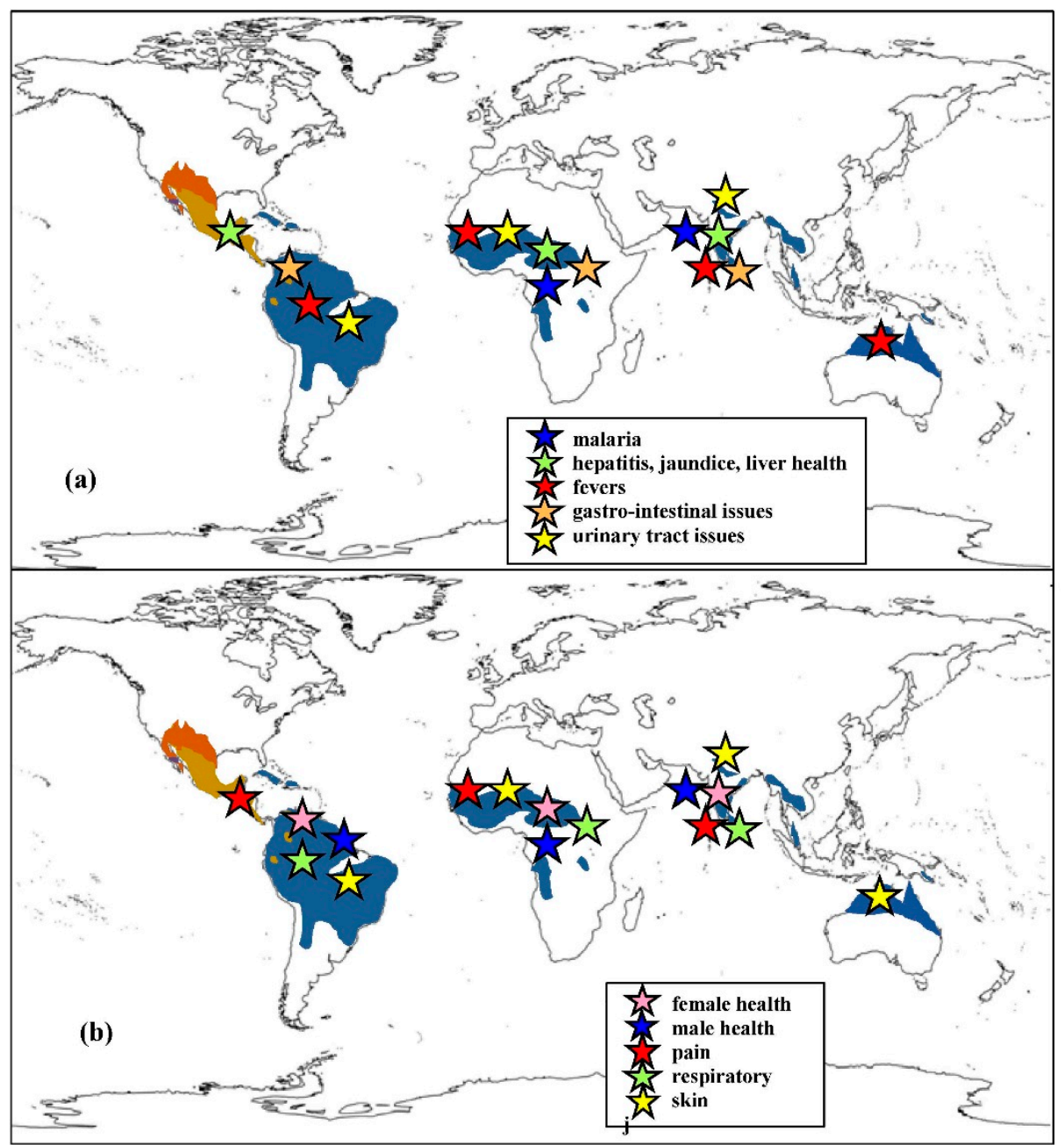

Figure 6. Comparing medicinal use throughout the geographic range of Cochlospermaceae. World maps illustrating general geographic regions where species of Cochlospermacea are being used to treat similar ailments: (a) malaria, hepatitis/jaundice/liver ailments, fevers, gastro-intestinal issues, and urinary tract issues; (b) female and male health issues, pain, respiratory ailments, and skin issues. Medicinal uses were divided between two maps to avoid overlapping stars. 
Cochlospermum vitifolium (Mexico, Central America, South America), C. religiosum (India), C. angolense (Angola), and C. planchonii and C. tinctorium (West Africa) are all used as treatments for jaundice and hepatitis, and also for general liver health (Figures 5 and 6). Five species are used to treat fevers in all four of the major geographic regions: C. orinocense in South America, C. religiosum in India, C. planchonii and C. tinctorium in West Africa, and C. fraseri in Australia (Figures 5 and 6).

As well as illustrating the number of medicinal uses per species, Figure 3 also shows the number of pharmacological studies conducted which have tested the bioactivity of many of the species, including one species, Cochlospermum gillivraei Benth., that doesn't have any documented medicinal uses. Many of these pharmacological studies found extracts from tested species to be potentially effective and safe medicines through in vitro and/or in vivo laboratory studies [42,48,50-52,59-61,72,83-107]. Cochlospermum tinctorium, from West Africa, was found to be the species with the highest number of medicinal uses and has been the focus of many bioscreening studies (Figures 3 and 7).

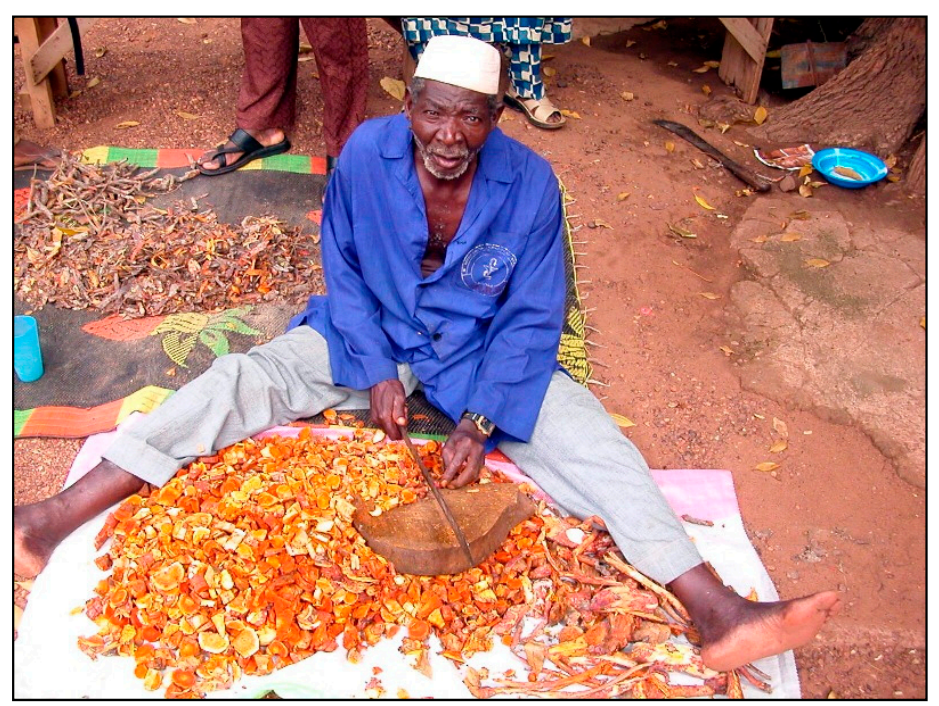

Figure 7. Dried tuberous root of Cochlospermum tinctorium being prepared to be sold at a market in Bamako, Mali, West Africa. Photo used with permission. Copyright Sergio Giani, Archives d'Aidemet Ong.

Extracts of Cochlospermum tinctorium from West Africa were found to be antimicrobial, antiviral, antimalarial, anti-tumor, anti-ulcer, and hepatoprotective [52,72,85,87,98,104,107]. Cochlospermum planchonii, also from West Africa, was also found to be antimalarial and hepatoprotective in laboratory studies $[60,61,108,109]$. Another African species exhibiting positive laboratory results as an antimalarial is C. angolense, from Angola $[76,90,91]$. Cochlospermum vitifolium and C. regium, from the Americas, were both found to be analgesic and anti-inflammatory. In addition, C. vitifolium was discovered to be antihypertensive and antidiabetic and C. regium was found to be antimicrobial and toxic to cancer cells $[97,100-103,110]$. One pharmacological study supports the use of $C$. religiosum as a treatment for eye afflictions. Devi et al. [111] discovered that a bioactive flavonoid (IR3G) isolated from the leaves of C. religiosum protected enucleated rat lenses from sodium selenite-induced cataract formation in vitro. These pharmacological studies provide substantial evidence that many of the traditional medicines from Cochlospermum species are effective and may even be more effective than modern treatments due to the rise of parasite and bacterial resistance [112,113]. Many species of Cochlospermaceae have yet to be studied for pharmacological activity.

In this study, ethnomedicinal data were mapped onto a previously-published molecular phylogeny [35] to be used as a framework to identify and evaluate correlations between the evolutionary relatedness among species and ethnobotanical uses by multiple ethnic groups in different geographic regions (Figures 8-11). Species sharing a most recent common ancestor generally produce 
similar secondary metabolites (bioactive compounds) because they share the same or similar metabolic pathways. This predictive nature of phylogenies can be used for drug discovery and to guide studies that provide additional support of effectiveness of target species [23,28,29,114].
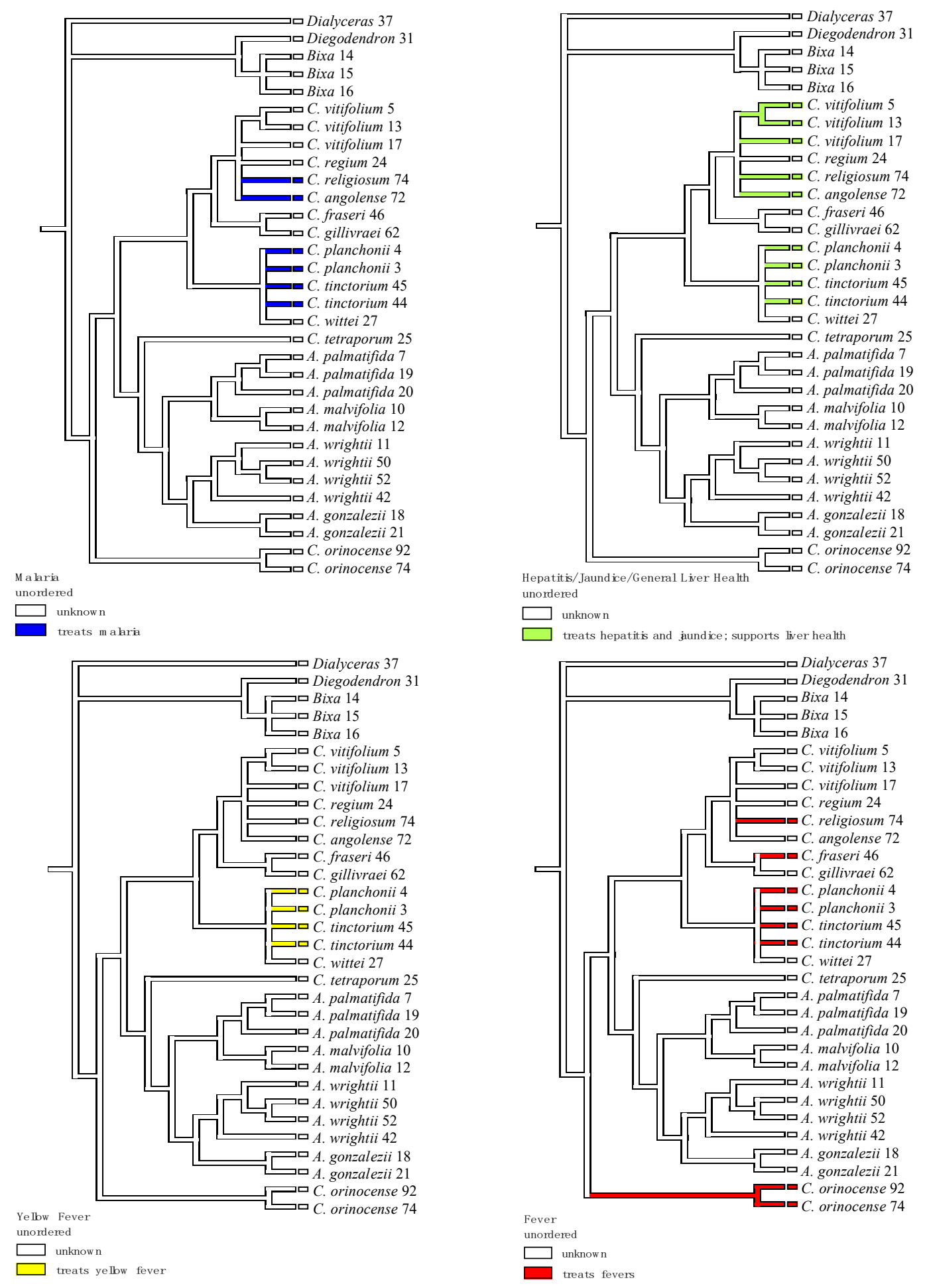

Figure 8. Medicinal uses (treatments for malaria, hepatitis/jaundice/other liver issues, yellow fever, and general fever) shared by two or more species mapped (as unordered character states) onto the Bayesian inference phylogeny of Cochlospermaceae of the combined nuclear (ITS) and plastid (trnG and $\operatorname{trn} L-F$ ) regions from Johnson-Fulton and Watson [35]. 

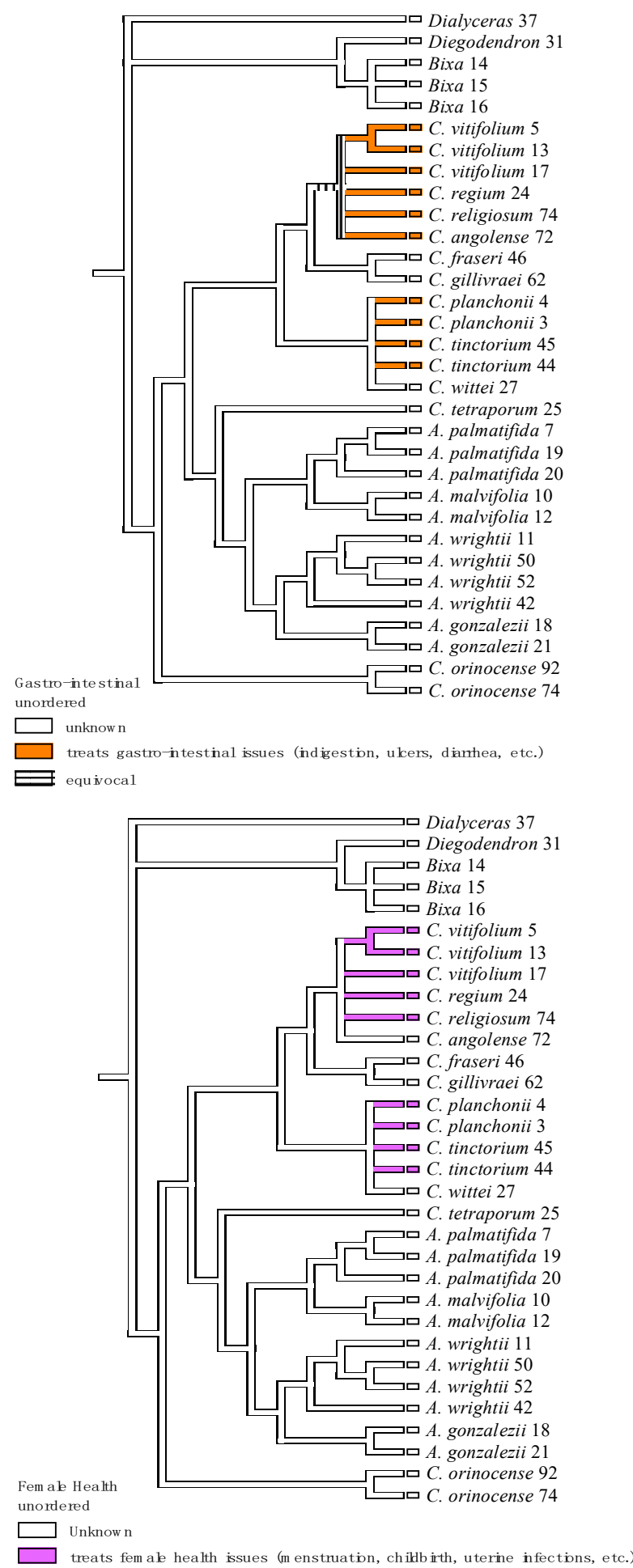
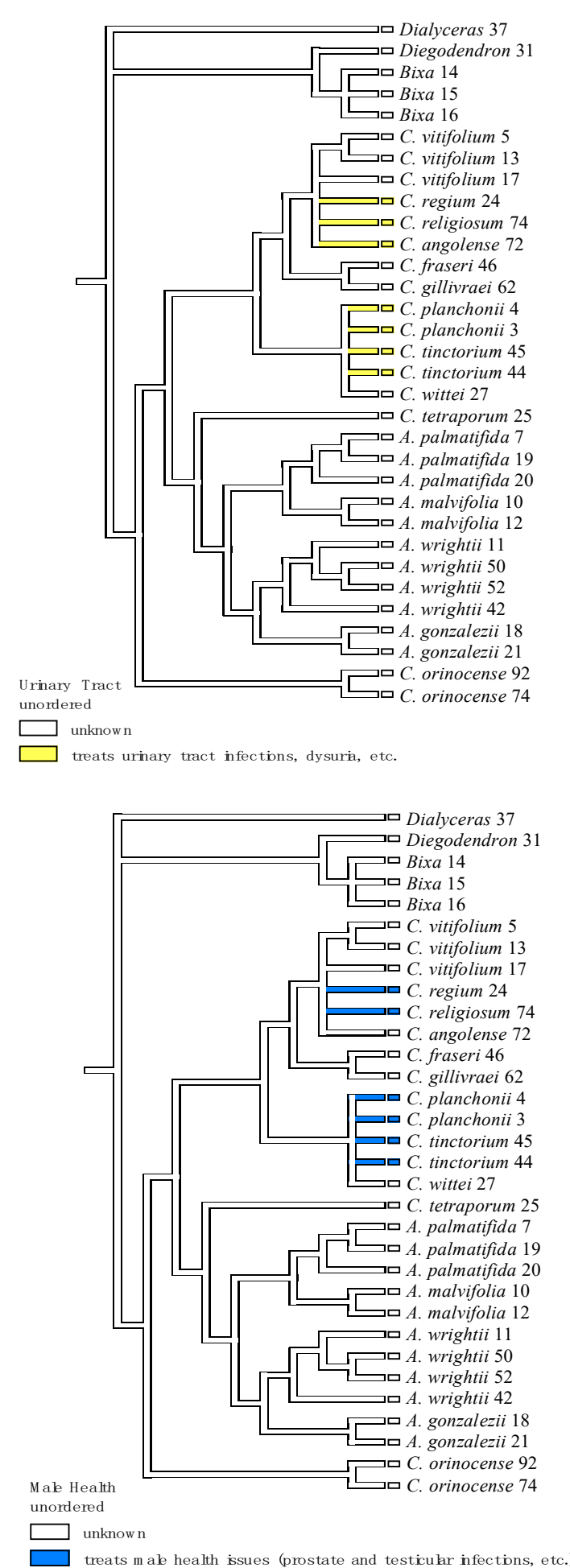

Figure 9. Medicinal uses (treatments for gastro-intestinal, urinary tract, female health, and male health issues) shared by two or more species mapped (as unordered character states) onto the Bayesian inference phylogeny of Cochlospermaceae of the combined nuclear (ITS) and plastid (trnG and trnL-F) regions from Johnson-Fulton and Watson [35]. 

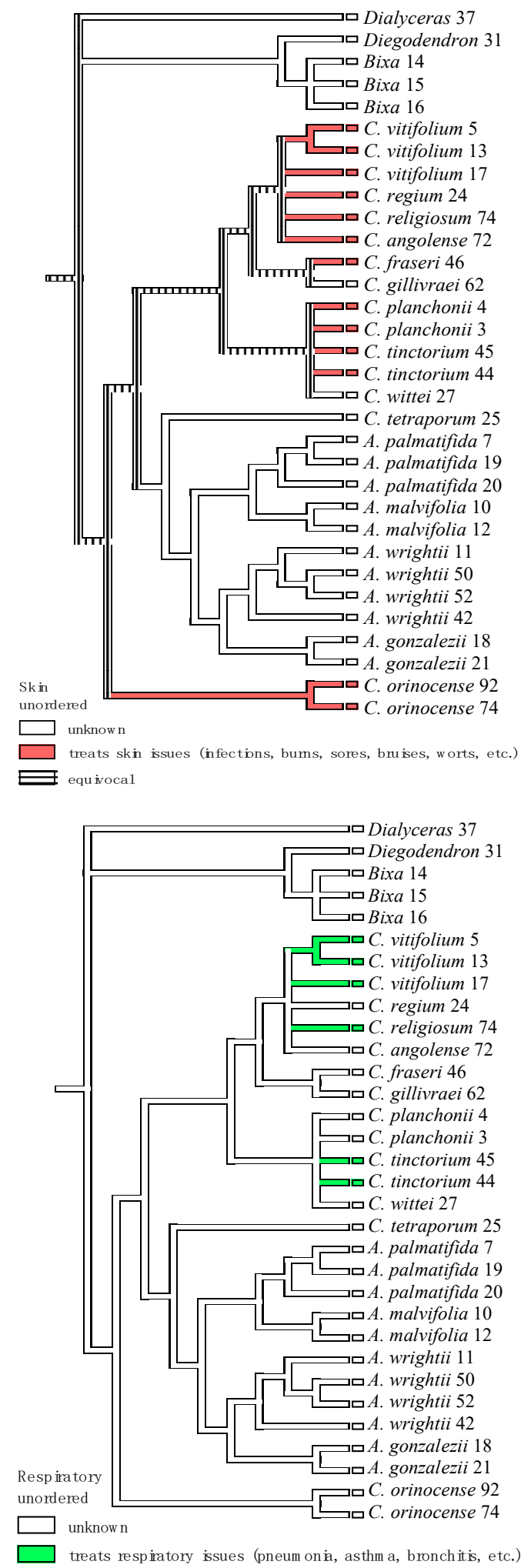
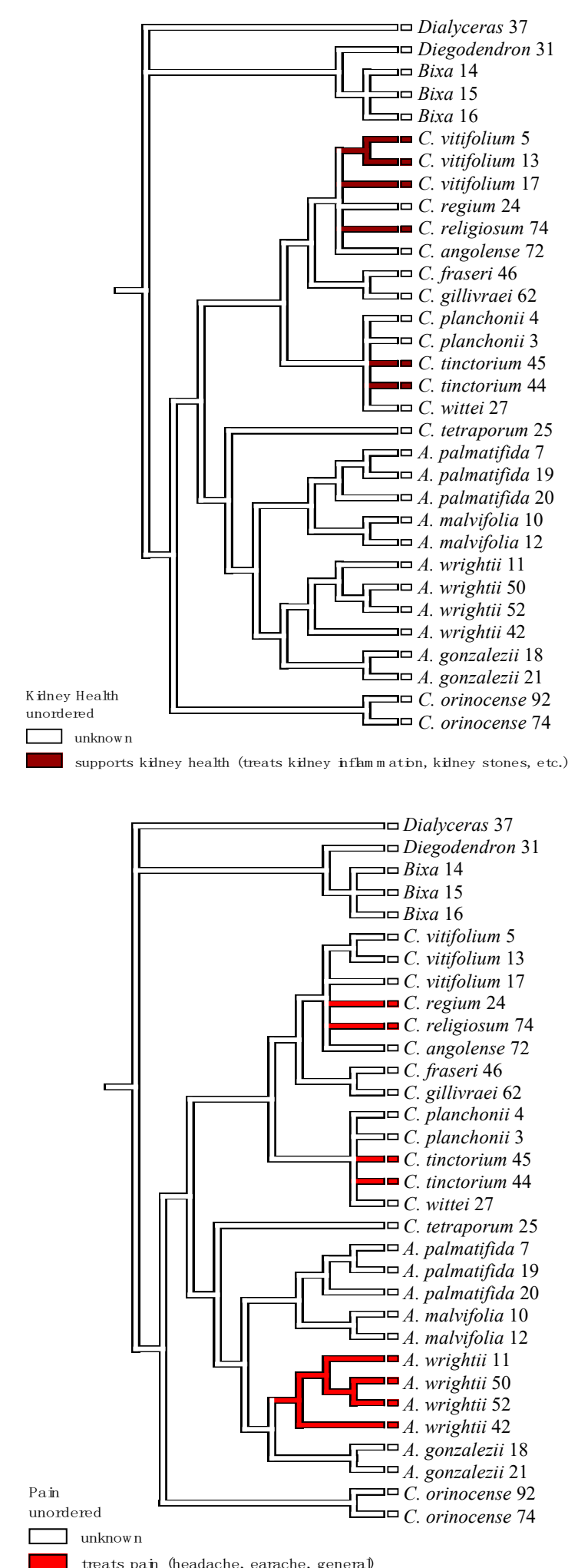

Figure 10. Medicinal uses (treatments for skin, kidney, and respiratory ailments and general pain) shared by two or more species mapped (as unordered character states) onto the Bayesian inference phylogeny of Cochlospermaceae of the combined nuclear (ITS) and plastid ( $\operatorname{trn} G$ and $\operatorname{trnL}-F$ ) regions from Johnson-Fulton and Watson [35]. 


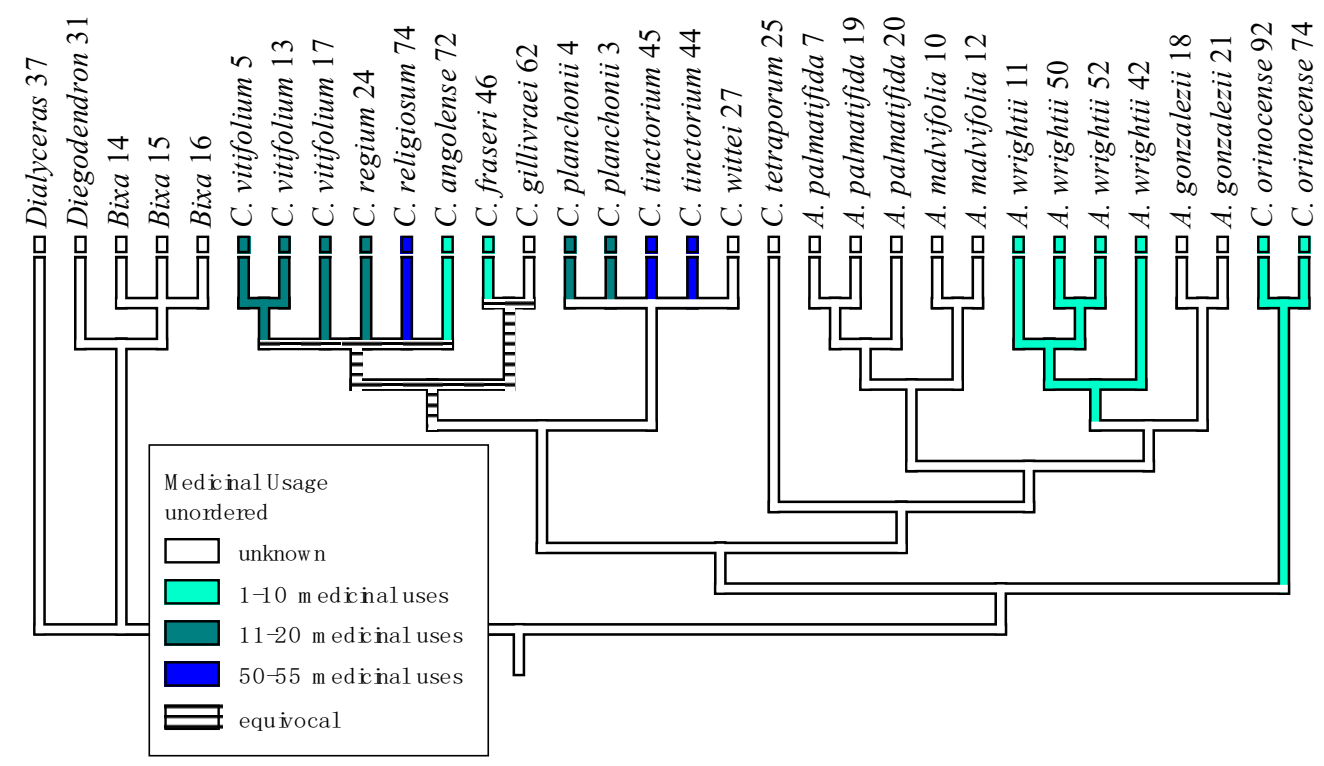

Figure 11. Number of medicinal uses of each species mapped (as unordered characters) onto the Bayesian inference phylogeny of Cochlospermaceae of the combined nuclear (ITS) and plastid (trnG and $\operatorname{trn} L-F$ ) regions from Johnson-Fulton and Watson [35].

Based on the results of this study, it is apparent that the species used for a medicinal use are often closely related, with a strong phylogenetic signal for a specific medicinal property (Figures 8-10). The lineage showing the most medicinal uses is the small clade (branch) of African species including Cochlospermum tinctorium, C. planchonii, and C. wittei Robyns which are all suffrutescent subshrubs (Figure 11). Of those three species, C. wittei is the only species lacking documented medicinal uses. This clade in the phylogeny is sister to another closely related group of species that includes all 'core' species of Cochlospermum (excluding C. orinocense and C. tetraporum Hallier f.), many of which share medicinal uses.

This high level of similar medicinal uses among closely related species may be due to the shared presence of bioactive compounds. In searching for new medicines, those species not being used to treat a specific illness while their closely related species are, such as is the case for $C$. wittei, could be potential candidates for bioscreening studies and they should be examined for more geographically localized medicinal use. Since they are closely related, they likely share medicinally-active compounds. Similarly, Rønsted et al. [21] found medicinally-active alkaloids in Narcissus in closely related species and suggested that phylogenetic relatedness could be used to make predictions about the presence of those same compounds in uninvestigated species. Thus, placing medicinal uses and/or the presence of bioactive compounds in a phylogenetic framework can make it possible to target species for further research. Species that are closely related to species commonly used as plant medicines may be harboring those same medicinal compounds, perhaps even at higher levels or slightly modified with greater effectiveness.

Four species in the major core Cochlospermum clade are used to treat malaria with three of the four having been positively screened for their high level of antimalarial activity (Figure 8) [60,61,76,90,91, 104,107-109]. Since malaria is such a problem in tropical regions of the world, and since Plasmodium resistance is so prevalent, the search for new antimalarials remains important. The other African subshrub species, C. wittei, the two core Cochlospermum species from the Americas (C. vitifolium and C. regium), and the two species from Australia (C. fraseri and C. gillivraei) may be strong candidates in the search for new antimalarial medicines, especially since some have already exhibited medicinal bioactivity. This method of combining phylogenetics, ethnobotany, and biogeography to discover new medicines appears to be much more efficacious than random screening of plants or through ethnobotanical studies alone. 
The use categories with the highest number of documented uses and the highest number of species of Cochlospermaceae being used as treatments are gastro-intestinal complaints and skin issues (Figures 4 and 5). In the phylogeny optimized for skin treatments (Figure 10), nearly all of the core Cochlospermum species are used to treat skin ailments, in addition to C. orinocense which is placed outside the core Cochlospermum clade in the phylogeny. This includes eight species across the four major geographic regions of the Americas, Africa, India, and Australia. This global use for these closely related, similar species, and the positive results from anti-microbial, anti-tumor, and anti-ulcer research offer strong support for the effectiveness of these skin related treatments $[52,72,85,87,98]$. Many of these same studies also support the ethnomedicinal uses related to gastro-intestinal issues.

\section{Conclusions}

Within Cochlospermaceae there are many similar medicinal uses among closely related plant species of different geographic regions among diverse cultural groups. Closely related species of Cochlospermaceae being used by cultural groups of different geographic regions to treat the same illness, suggests that these species and other closely related species may contain bioactive chemical compounds with potential biomedical value because they may represent independent discoveries by different cultural groups of similar medicinally-active compounds. Some of these patterns could be due to cultural exchange, such as similar uses between South America and Africa due to diaspora of African slaves into the Americas. However, because there are so many similar use patterns among the species, and because the geographic scale of this study is so large, we propose that those instances, while possible, are few or unlikely. There is also a small chance that these common ethnobotanical patterns could be due to chance rather than the presence of bioactive properties. Perhaps some of the similarities of use could be due to the plants sharing similar morphological characters, such as yellow flowers and sap which could lead different groups to use similar species to treat illnesses that are connected with the color yellow, such as the treatments for jaundice, hepatitis, liver health, yellow fever, and urinary tract issues. This phenomenon, known as the Doctrine of Signatures, would be challenging to test [115].

This study is one of few to take a multidisciplinary approach to explore cross-cultural ethnobotanical patterns at a large geographic scale in a phylogenetic framework. For such a small family, Cochlospermaceae harbors many species with important ethnobotanical uses. Greater effort should be made to study the pharmacological activity of these species that share medicinal uses throughout their geographic ranges, as well as those closely related species as determined through molecular phylogenetics research. It remains valuable to continue to gather ethnobotanical data in the field as well as study the effects of wild harvesting on natural populations and the options for cultivation of those species that are highly used and/or rare in occurrence. More investigation on the distribution patterns, population density and regeneration of these species could help with planning and establishing harvest regulations that assure a sustainable supply of plant materials.

Author Contributions: Conceptualization, Formal Analysis, Investigation, and Writing-Original Draft Preparation, S.B.J.-F.; Writing-Review, Editing, and Supervision, L.E.W.

Funding: This research was funded in part by Miami University Academic Challenge Grants, Miami University's Willard Sherman Turrell Herbarium collection grants, and Shasta College.

Acknowledgments: We would like to thank Sergio Giani for the use of his photo of the selling of Cochlospermum tinctorium at a market in Mali. We would like to acknowledge the Willard Sherman Turrell Herbarium at Miami University where the voucher specimens used for the molecular phylogenies in Fulton-Johnson and Watson [35] have been deposited. We would also like to thank those who reviewed this manuscript and the editors of this journal who supplied helpful input.

Conflicts of Interest: The authors declare no conflict of interest. The funders had no role in the design of the study; in the collection, analyses, or interpretation of data; in the writing of the manuscript, or in the decision to publish the results. 


\section{References}

1. Farnsworth, N.R.; Soejarto, D.D. Global importance of medicinal plants. In The Conservation of Medicinal Plants; Akerele, O., Heywood, V., Synge, H., Eds.; Cambridge University Press: Cambridge, UK, 1991.

2. Balick, M.J.; Cox, P.A. Plants, People, and Culture: The Science of Ethnobotany; Scientific American Library: New York, NY, USA, 1996.

3. Evert, R.F.; Eichhorn, S.E. Raven Biology of Plants; W. H. Freeman: New York, NY, USA, 2012.

4. Raskin, I.; Ribnicky, D.M.; Komarnytsky, S.; Ilic, N.; Poulev, A.; Borisjuk, N.; Brinker, A.; Moreno, D.A.; Ripoll, C.; Yakoby, N.; et al. Plants and human health in the twenty-first century. Trends Biotechnol. 2002, 20, 522-531. [CrossRef]

5. Gurib-Fakim, A. Medicinal plants: Traditions of yesterday and drugs of tomorrow. Mol. Asp. Med. 2006, 27, 1-93. [CrossRef] [PubMed]

6. Benz, B.F.; Cevallos, J.; Santana, F.; Rosales, J. Losing knowledge about plant use in the Sierra de Manantlan Biosphere Reserve, Mexico. Econ. Bot. 2000, 54, 183-191. [CrossRef]

7. Sutherland, W.J. Parallel extinction risk and global distribution of languages and species. Nature 2003, 423, 276-279. [CrossRef] [PubMed]

8. Arora, N.K. Biodiversity conservation for sustainable future. Environ. Sustain. 2018, 1, 109-111. [CrossRef]

9. Glikson, A. The lungs of the Earth: Review of the carbon cycle and mass extinction of species. Energy Procedia 2018, 146, 3-11. [CrossRef]

10. Saslis-Lagoudakis, C.H.; Klitgaard, B.B.; Forest, F.; Francis, L.; Savolainen, V.; Williamson, E.M.; Hawkins, J.A. The use of phylogeny to interpret cross-cultural patterns in plant use and guide medicinal plant discovery: An example from Pterocarpus (Leguminosae). PLoS ONE 2011, 6, e22275. [CrossRef] [PubMed]

11. Poppendieck, H.H. A Monograph of the Cochlospermaceae. Bot. Jahrb. 1980, 101, 191-265.

12. Poppendieck, H.H. Flora Neotropica Monograph, No. 27: Cochlospermaceae; New York Botanical Garden: New York, NY, USA, 1981.

13. Poppendieck, H.H. Cochlospermaceae. In The Families and Genera of Vascular Plants; Kubitzki, K., Bayer, C., Eds.; Springer: Berlin, Germany, 2003; Volume 5, pp. 71-74.

14. Morton, J.F. Atlas of Medicinal Plants of Middle America: Bahamas to Yucatan; Charles, C. Thomas Publisher: Springfield, IL, USA, 1981.

15. Abbiw, D. Useful Plants of Ghana; Intermediate Technology Publications and Royal Botanic Gardens: Kew, UK, 1990.

16. Sala, A.V. Indian Medicinal Plants: A Compendium of 500 Species; Orient Longman Ltd.: Madras, India, 1994; Volume 2.

17. Hodgson, W.C. Food Plants of the Sonoran Desert; University of Arizona Press: Tucson, AZ, USA, 2001.

18. Pullaiah, T. Medicinal plants in Andhra Pradesh, India; Regency Publications: New Delhi, India, 2002.

19. Yetman, D.A.; Van Devender, T.R. Mayo Ethnobotany; University of California Press: Berkeley, CA, USA, 2002.

20. Fabricant, D.S.; Farnsworth, N.R. The value of plants used in traditional medicine for drug discovery. Environ. Health Perspect. 2001, 109, 69-75. [PubMed]

21. Rønsted, N.; Savolainen, V.; Mølgaard, P.; Jäger, A.K. Phylogenetic selection of Narcissus species for drug discovery. Biochem. Syst. Ecol. 2008, 36, 417-422. [CrossRef]

22. Zhu, F.; Qin, C.; Tao, L.; Liu, X.; Shi, Z.; Ma, X.; Jia, J.; Tan, Y.; Cui, C.; Lin, J.; et al. Clustered patterns of species origins of nature-derived drugs and clues for future bioprospecting. Proc. Natl. Acad. Sci. USA 2011, 108, 12943-12948. [CrossRef] [PubMed]

23. Rønsted, N.; Symonds, M.R.E.; Birkholm, T.; Christensen, S.; Meerow, A.W.; Molander, M.; Mølgaard, P.; Petersen, G.; Rasmussen, N.; van Staden, J.; et al. Can phylogeny predict chemical diversity and potential medicinal activity of plants? A case study of Amaryllidaceae. BMC Evol. Biol. 2012, 12, 182. [CrossRef] [PubMed]

24. Saslis-Lagoudakis, C.H.; Savolainen, V.; Williamson, E.M.; Forest, F.; Wagstaff, S.J.; Baral, S.R.; Watson, M.F.; Pendry, C.A.; Hawkins, J.A. Phylogenies reveal predictive power of traditional medicine in bioprospecting. Proc. Natl. Acad. Sci. USA 2012, 109, 15835-15840. [CrossRef] [PubMed]

25. Hao, D.; Xiao, P. Genomics and evolution in traditional medicinal plants: Road to a healthier life. Evol. Bioinform. 2015, 11, 197-212. [CrossRef] [PubMed] 
26. Yessoufou, K.; Daru, B.; Muasya, A.M. Phylogenetic exploration of commonly used medicinal plants in South Africa. Mol. Ecol. Resour. 2015, 15, 405-413. [CrossRef] [PubMed]

27. Garnatje, T.; Peñuelas, J.; Vallès, J. Ethnobotany, Phylogeny, and 'Omics' for Human Health and Food Security. Trends Plant Sci. 2017, 22, 187-191. [CrossRef] [PubMed]

28. Maldonado, C.; Barnes, C.J.; Cornett, C.; Holmfred, E.; Hansen, S.H.; Persson, C.; Antonelli, A.; Rønsted, N. Phylogeny predicts the quantity of antimalarial alkaloids within the iconic yellow Cinchona bark (Rubiaceae: Cinchona calisaya). Front. Plant Sci. 2017, 8, 391. [CrossRef] [PubMed]

29. Liu, K.; Morita, A.H.; Kanaya, S.; Altaf-Ul-Amin, M. Metabolite-content-guided prediction of medicinal/edible properties in plants for bioprospecting. Curr. Res. Compliment. Altern. Med. 2018. [CrossRef]

30. Terashima, H.; Ichikawa, M. A comparative ethnobotany of the Mbuti and Efe hunter-gatherers in the Ituri forest, Democratic Republic of Congo. Afr. Study Monogr. 2003, 24, 1-168.

31. Prescott, T.A.K.; Kiapranis, R.; Maciver, S.K. Comparative ethnobotany and in-the-field antibacterial testing of medicinal plants used by the Bulu and inland Kaulong of Papua New Guinea. J. Ethnopharmacol. 2012, 139, 497-503. [CrossRef] [PubMed]

32. Ghorbani, A.; Langenberger, G.; Sauerborn, J. A comparison of the wild food plant use knowledge of ethnic minorities in Naban River Watershed National Nature Reserve, Yunnan, SW China. J. Ethnobiol. Ethnomed. 2012, 8, 17. [CrossRef] [PubMed]

33. Alexiades, M.N. Selected Guidelines for Ethnobotanical Research: A Field Manual; Botanical Garden: New York, NY, USA, 1996.

34. Martin, G.J. Ethnobotany: A Method's Manual; Routledge: Abingdon, UK, 2004.

35. Johnson-Fulton, S.; Watson, L. Phylogenetic Systematics of Cochlospermaceae (Malvales) Based on Molecular and Morphological Evidence. Syst. Bot. 2017, 42, 271-282. [CrossRef]

36. Maddison, D.R.; Maddison, W.P. MacClade 4: Analysis of Phylogeny and Character Evolution. Version 4.08a. 2005. Available online: http:/ / macclade.org (accessed on 20 August 2013).

37. Martinez, M. Las Plantas Medicinales de Mexico, Quinta ed.; Ediciones Botas: Mexico City, Mexico, 1969.

38. Esposito-avella, M.; Brown, P.; Tejeira, I.; Buitrago, R.; Barrios, L.; Sanchez, C.; Gupta, M.P.; Cedeño, J. Pharmacological screening of Panamanian medicinal plants. Part 1. Pharm. Biol. 1985, 23, 17-25. [CrossRef]

39. Salas, T.P.; Peraza, L.S. Lista Anotada de las Plantas Medicinales de Uso Actual en el Estado de Quintana Roo, Mexico; Centro de Investigaciones de Qintana Roo: Chetumal, Mexico, 1993.

40. Zamora-Martinez, M.C.; Pola, C.N.P. Medicinal plants used in some rural populations of Oaxaca, Puebla and Veracruz, Mexico. J. Ethnopharmacol. 1992, 35, 229-257. [CrossRef]

41. Stebbins, M. Flowering Trees of Florida; Pineapple Press Inc.: Sarasota, FL, USA, 1999.

42. Caballero-George, C.; Vanderheyden, P.M.L.; Solis, P.N.; Pieters, L.; Shahat, A.A.; Gupta, M.P.; Vauquelin, G.; Vlietinck, A.J. Biological screening of selected medicinal Panamanian plants by radioligand-binding techniques. Phytomedicine 2001, 8, 59-70. [CrossRef] [PubMed]

43. Cedano, M.M.; Villasenor, I.L. Usos y nombres communes de lase species de Cochlospermaceae en Mexico. Ethnobiologia 2004, 4, 73-88.

44. Zuchowski, W. A Guide to Tropical Plants of Costa Rica; Zona Tropical Publication: Ithaca, NY, USA, 2006.

45. Monroy-Ortíz, C.; España, P.C. Plantas Medicinales Utilizadas en el Estado de Morelos; Universidad Autónoma del Estado de Morelos: Cuernavaca, Morelos, Mexico, 2007.

46. Lewis, A.C.; Hanson, P.J. Anti-ulcer drugs of plant origin. Prog. Med. Chem. 1991, 28, 201-231. [PubMed]

47. Salles, A.H.; Reis, G.M.C.I.; Zurlo, M.A. Horto Medicinal do Cerrado; Jardim Botanico de Brasilia: Brasília, Brazil, 1997.

48. Nunes, W.B.; de Carvalho, S. Evaluation of the mutagenic potential of Cochlospermum regium in Drosophila melanogaster male germ cells. Genet. Mol. Biol. 2003, 26, 545-549. [CrossRef]

49. Rodrigues, E.; Carlini, E.A. Ritual use of plants with possible action on the central nervous system by the Kraho Indians, Brazil. Phytother. Res. 2005, 19, 129-135. [CrossRef] [PubMed]

50. Ceschini, L.; Campos, E.G. Cytotoxic effects of Cochlospermum regium (Mart \& Schrank) Pilger aqueous root extract on mammalian cells. J. Ethnopharmacol. 2006, 103, 302-305. [PubMed]

51. Andrade, L.S.; Santos, D.B.; Castro, D.B.; Guillo, L.A.; Chen, L. Absence of antimutagenicity of Cochlospermum regium (Mart. and Schr.) Pilger 1924 by micronucleus test in mice. Braz. J. Biol. 2008, 68, 155-159. [CrossRef] [PubMed] 
52. Solon, S.; Carollo, C.A.; Brandão, L.F.G. Phenolic derivatives and other chemical compounds from Cochlospermum regium. Quim. Nova 2012, 35, 1169-1172. [CrossRef]

53. Rutter, R.A. Catálogo de Plantas Utiles de la Amazonía Peruana; Instituto Lingüístico de Verano: Yarinacocha, Peru, 1990.

54. Duke, J.A.; Vasquez, R. Amazonian Ethnobotanical Dictionary; CRC Press: Boca Raton, FL, USA, 1994.

55. Adam, J.G.; Echard, N.; Lescot, M. Plantes médicinales Hausa de l'Ader (République du Niger). J. Agric. Trop. Bot. Appl. 1972, 19, 259-399. [CrossRef]

56. Adjanohoun, E.; Ahyi, M.R.A.; Assi, L.A.; Dicko, L.D.; Daouda, H.; Delmas, M.; de Souza, S.; Garba, M.; Guinko, S.; Kayonga, A.; et al. Medecine Traditionnelle et Pharmacopee: Contribution Aux études Ethnobotaniques et Floristiques au Niger; Agence de Coopération Culturelle et Technique: Paris, France, 1980.

57. Aké Assi, L.; Guinko, S. Plants Used in Traditional Medicine in West Africa; Roche Editions: Basel, Switzerland, 1991.

58. Etkin, N.L.; Ross, P.J. Recasting malaria, medicine, and meals: A perspective on disease adaptation. In The Anthropology of Medicine: From Culture to Method; Romanucci-Ross, L., Moerman, D.E., Tancredi, L.R., Eds.; Bergin \& Garvey: New York, NY, USA, 1991.

59. Aliyu, R.; Okoye, Z.S.C.; Shier, W.T. The hepatoprotective cytochrome P-450 enzyme inhibitor isolated from the Nigerian medicinal plant Cochlospermum planchonii is a zinc salt. J. Ethnopharmacol. 1995, 48, 89-97. [CrossRef]

60. Benoit, F.; Valentin, A.; Pélissier, Y.; Marion, C.; Dakuyo, Z.; Mallié, M.; Bastide, J.M. Antimalarial activity in vitro of Cochlospermum tinctorium tubercle extracts. Trans. R. Soc. Trop. Med. Hygiene 1995, 89, 217-218. [CrossRef]

61. Vonthron-Senecheau, C.; Weniger, D.; Ouattara, M.; Bi, F.T.; Kamenan, A.; Lobstein, A.; Brun, R.; Anton, R. In vitro antiplasmodial activity and cytotoxicity of ethnobotanically selected Ivorian plants. J. Ethnopharmacol. 2003, 87, 221-225. [CrossRef]

62. Phytofla Laboratory. Les Laboratoires Phytofla. Available online: https://laboratoiresphytofla.com (accessed on 29 July 2012).

63. Thiombiano, A.; Schmidt, M.; Dressler, S.; Ouédraogo, A.; Hahn, K.; Zizka, G. Catalogue des Plantes Vasculaires du Burkina Faso; Boissiera 65, Ed.; Conservatoire et Jardin Botaniques de la Ville de Genève: Geneva, Switzerland, 2012.

64. Dalziel, J.M.; Hutchinson, J. The Useful Plants of West Tropical Africa; Published under the Authority of the Secretary of State for the Colonies by the Crown Agents for the Colonies: London, UK, 1937.

65. Kerharo, J.; Bouquets, A. Plantes Medicinales et Toxiques de la Côte d'Ivoire-Haute Volta; Vigot Frères: Paris, France, 1950.

66. Kerharo, J.; Adam, J.G. La Pharmacopee Sénégal aise Traditionnelle: Plantes Medicinales Et Toxiques; Vigot Frères: Paris, France, 1974.

67. Berhaut, J. Flore illustrée du Sénégal. Tome 2. Ministère Déve-loppement Rural: Direction des Eaux E Forets et Ed; Clairafrique: Dakar, Senegal, 1974.

68. Burkill, H.M. The Useful Plants of West Tropical Africa, 2nd ed.; Families, A.-D., Ed.; Royal Botanical Gardens: Kew, UK, 1985.

69. Diniz, M.A.; Silva, O.; Paulo, M.A.; Gomes, E.T. Medicinal uses of plants from Guinea-Bissau. In The Biodiversity of African Plants; van der Maesen, L.J.G., Ed.; Kluwer: Dordrecht, The Netherlands, 1996.

70. Neuwinger, H.D. African Ethnobotany: Poisons and Drugs: Chemistry, Pharmacology, Toxicology; Chapman \& Hall: London, UK, 1996.

71. Jansen, P.C.M.; Cardon, D. (Eds.) Plant Resources of Tropical Africa (PROTA) 3. Dyes and Tannins; PROTA Foundation: Wageningen, The Netherlands, 2005.

72. Nergard, C.S.; Diallo, D.; Inngjerdingen, K.; Michaelsen, T.E.; Matsumoto, T.; Kiyohara, H.; Yamada, H.; Paulsen, B.S. Medicinal use of Cochlospermum tinctorium in Mali: Anti-ulcer-, radical scavenging- and immunomodulation activities of polymers in the aqueous extract of the roots. J. Ethnopharmacol. 2005, 96, 255-269. [CrossRef] [PubMed]

73. Togola, A.; Diallo, D.; Dembele, S.; Barsett, H.; Paulsen, B.S. Ethnopharmacological survey of different uses of seven medicinal plants from Mali, (West Africa) in the regions Doila, Kolokani and Siby. J. Ethnobiol. Ethnomed. 2005, 1, 7. [CrossRef] [PubMed] 
74. Bosch, C.H.; Borus, D.J. (Eds.) Dyes and Tannins of Tropical Africa; Conclusions and Recommendations Based on PROTA 3: 'Dyes and tannins'; PROTA Foundation: Wageningen, The Netherlands, 2006.

75. Angola: Country Report to the International Conference and Programme on Plant Genetic Resource. In Proceedings of the International Conference on Plant Genetic Resources, Leipzig, Gemany, 17-23 June 1996; Food and Agriculture Organization of the United Nations (FAO): Rome, Italy, 1996.

76. Presber, W.; Hegenscheid, B.; Hernandez-Alvarez, H.; Herrmann, D.; Brendel, C. Inhibition of the growth of Plasmodium falciparum and Plasmodium berghei in vitro by an extract of Cochlospermum angolense (Welw.). Acta Trop. 1992, 50, 331-338. [CrossRef]

77. Howes, F.N. Vegetable Gums and Resins; Chronica Botanica: Waltham, MA, USA, 1949.

78. Jain, N.; Babbar, S.B. Gum katira-A cheap gelling agent for plant tissue culture media. Plant Cell Tissue Organ Cult. 2002, 71, 223-229. [CrossRef]

79. Panda, H. Hand Book of Ayurvedic Medicines with Formulae, Processes, and Their Uses; National Institute of Industrial Research: Delhi, India, 2004.

80. Vegi, G.M.N.; Sistla, R.; Srinivasan, P.; Beedu, S.R.; Khar, R.K.; Diwan, P.V. Emulsifying properties of gum kondagogu (Cochlospermum gossypium), a natural biopolymer. J. Sci. Food Agric. 2008, 89, 1271-1276. [CrossRef]

81. Low, T. Bush Medicine: A Pharmacopoeia of Natural Remedies; Angus \& Robertson: Melbourne, Australia, 1990.

82. Devanesen, D.D. Traditional Aboriginal Medicine Practice in the Northern Territory of Australia. Presented at the International Symposium on Traditional Medicine, Awaji Island, Japan, 11-13 September 2000.

83. Cook, I.F.; Knox, J.R. Flavonoids from Cochlospermum gillivraei. Phytochemistry 1975, 14, $2510-2511$. [CrossRef]

84. Etkin, N.L. A Hausa herbal pharmacopoeia: Biochemical evaluation of commonly used plant medicines. J. Ethnopharmacol. 1981, 4, 75-98. [CrossRef]

85. Diallo, B.; Vanhaelen, M. Apocarotenoids from Cochlospermum tinctorium. Phytochemistry 1987, 26, 1491-1492. [CrossRef]

86. Diallo, B.; Vanhaelen, M.; Kiso, Y.; Hikino, H. Antihepatotoxic actions of Cochlospermum tinctorium rhizomes. J. Ethnopharmacol. 1987, 20, 239-243. [CrossRef]

87. Diallo, B.; Vanhaelen, M.; Vanhaelen-Fastre, R. Studies on inhibitors of skin-tumor promotion inhibitory effects of triterpenes from Cochlospermum tinctorium on Epstein-Barr virus activation. J. Nat. Prod. 1989, 52, 879-881. [CrossRef] [PubMed]

88. Diallo, B.; Vanhaelen-Fastre, R.; Vanhaelen, M.; Nkiani-Ibwala, N.Y.; Pelsener-Coremans, J. Antimicrobial activity of two apocarotenoids isolated from Cochlospermum tinctorium rhizome. Fitoterapia 1991, 62, 144-145.

89. Diallo, B.; Vanhaelen-Fastre, R.; Vanhaelen, M.; Fiegel, C.; Joyeux, M.; Roland, A.; Fleurentin, J. Further studies on the hepatoprotective effects of Cochlospermum tinctorium rhizomes. J. Ethnopharmacol. 1992, 36, 137-142. [CrossRef]

90. Presber, W.; Hegenscheid, B.; Friedmann-Alvermann, B.; Dörge, S.; Voigt, G.; Hiller, K.; Hils, J.; May, A.; Böthig, B. Antiviral activity of extracts of Cochlospermum angolense (Welw.). Die Pharm. 1987, 42, 707-708.

91. Presber, W.; Herrmann, D.K.; Hegenscheid, B. The effect of an extract from Cochlospermum angolense ("Burututu") on Plasmodium berghei in the mouse malaria suppression test. Angew. Parasitol. 1991, 32, 7-9. [PubMed]

92. Dalvi, R.R.; Séré, A. Protective effect of Cochlospermum tinctorium A. rich extract versus Aflatoxin B induced liver damage in rats. Pharm. Biol. 1988, 26, 117-120. [CrossRef]

93. Castro, M.S.A.; Siqueira, J.M.; Krieger-Amorin, L.W.; Souza, K.C.B. Efeito analgésico e antiedematogênico do Cochlospermum regium (Mart.) Pilger ('algodãozinho'). In Proceedings of the XIII Simpósio de Plantas Medicinais do Brasil, Fortaleza, Brazil, 6-9 September 1994.

94. Castro, M.S.A.; Siqueira, J.M.; Vanderline, F.A. Envolvimento de receptores dopaminérgicos no efeito antinociceptivo de uma flavanona isolada dos rizomas de Cochlospermum regium. In Proceedings of the Anais do XV Simpósio de Plantas Medicinais do Brasil, Águas de Lindóia, Brazil, 15 August 1998.

95. Oliveira, C.C.; de Siqueira, J.M.; de Souza, K.C.B.; Resende, U.M. Avaliação da atividade bacteriana da raiz de Cochlospermum regium "algodãozinho do campo". In Proceedings of the XIII Simpósio de Plantas Medicinais do Brasil, Fortaleza, Brazil, 6-9 September 1994.

96. Oliveira, C.C.; de Siqueira, J.M.; de Souza, K.C.B.; Resende, U.M. Antibacterial activity of rhizomes from Cochlospermum regium preliminary results. Fitotera 1996, 67, 176-177. 
97. Herrera, M.D.; Zarzuelo, A.; Jimenez, J.; Marhuenda, E.; Duarte, J. Effects of flavanoids on rat aortic smooth muscle contractility: Structure-activity relationships. Gener. Pharmacol. 1996, 27, 273-277. [CrossRef]

98. Toledo, M.I.; Siqueira, J.M.; Araujo, L.C.L.; Oga, S. Acute and subacute toxicity of Cochlospermum regium (Mart. \& Schr.) Pilger. Phytother. Res. 2000, 14, 359-361. [PubMed]

99. Ballin, N.Z.; Traoré, M.; Tinto, H.; Sittie, A.; Mølgaard, P.; Olsen, C.E.; Kharazami, A.; Christensen, S.B. Antiplasmodial compounds from Cochlospermum tinctorium. J. Nat. Prod. 2002, 65, 1325-1327. [CrossRef] [PubMed]

100. Ajay, M.; Gilani, A.U.; Mustafa, M.R. Effects of flavanoids on vascular smooth muscle of the isolated rat thoracic aorta. Life Sci. 2003, 19, 603-612. [CrossRef]

101. Sánchez-Salgado, J.C.; Ortiz-Andrade, R.R.; Aguirre-Crespo, F.; Vergara-Galicia, J.; León-Rivera, I.; Montes, S.; Villalobos-Molina, R.; Estrada-Soto, S. Hypoglycemic, vasorelaxant and hepatoprotective effects of Cochlospermum vitifolium (Willd.) Sprengel: A potential agent for the treatment of metabolic syndrome. J. Ethnopharmacol. 2007, 109, 400-405. [CrossRef] [PubMed]

102. Sanchez-Salgado, J.C.; Castillo-Espana, P.; Ibarra-Barajas, M.; Villalobos-Molina, R.; Estrada-Soto, S. Cochlospermum vitifolium induces vasorelaxant and antihypertensive effects mainly by activation of NO/cGMP signaling pathway. J. Ethnopharmacol. 2010, 130, 477-484. [CrossRef] [PubMed]

103. Ortiz-Andrade, R.R.; Sánchez-Salgado, J.C.; Navarrete-Vázquez, G.; Webster, S.P.; Binnie, M.; García-Jiménez, S.; León-Rivera, I.; Cigarroa-Vázquez, P.; Villalobos-Molina, R.; Estrada-Soto, S. Antidiabetic and toxicological evaluations of naringenin in normoglycaemic and NIDDM rat models and its implications on extra-pancreatic glucose regulation. Diabetes Obes. Metab. 2008, 10, 1097-1104. [CrossRef] [PubMed]

104. Traoré, M.; Diallo, A.; Nikièma, J.B.; Tinto, H.; Dakuyo, Z.P.; Ouédraogo, J.B.; Guissou, I.P.; Guiguemdé, T.R. In vitro and in vivo antiplasmodial activity of 'Saye', an herbal Remedy used in Burkina Faso traditional medicine. Phytother. Res. 2008, 22, 550-551. [CrossRef] [PubMed]

105. Manso, J.A.X.; Figueiredo, F.R.G.; Hanusch, A.L.; Machado, R.C.; Cunha, D.M.C.; da Silva, C.C.; da Cruz, A.D. Bioensaio animal na avaliação da mutagenicidade do decocto de Cochlospermum regium (Cochlospermaceae). In Proceedings of the 2nd Reunião Brasileira de Citogenética, Águas de Lindóia, São Paulo, Brazil, 28-30 August 2011.

106. Willcox, M. Improved traditional phytomedicines in current use for the clinical treatment of malaria. Planta Med. 2011, 77, 662-671. [CrossRef] [PubMed]

107. Yerbanga, R.S.; Lucantoni, L.; Lupidi, G.; Dori, G.U.; Tepongning, N.R.; Nikiema, J.B.; Esposito, F.; Habluetzel, A. Antimalarial plant remedies from Burkina Faso: Their potential for prophylactic use. J. Ethnopharmacol. 2012, 140, 255-260. [CrossRef] [PubMed]

108. Benoit-vical, F.; Valentin, A.; Pelissier, Y.; Mallie, M.; Bastide, J.M.; Bessiere, J.M. In vitro antimalarial activity and cytotoxicity of Cochlospermum tinctorium and Cochlospermum planchonii leaf extracts and essential oils. Planta Med. 1999, 65, 378-381. [CrossRef] [PubMed]

109. Benoit-Vical, F.; Valentin, A.; Da, B.; Dakuyo, Z.; Descamps, L.; Mallie, M. N’Dribala (Cochlospermum planchonii) versus chloroquine for treatment of uncomplicated Plasmodium falciparum malaria. J. Ehtnopharmacol. 2003, 89, 111-114. [CrossRef]

110. Deharo, E.; Baelmans, R.; Gimenez, A.; Quenevo, C.; Bourdy, G. In vitro immunomodulatory activity of plants used by the Tacana ethnic group in Bolivia. Phytomedicine 2004, 11, 516-522. [CrossRef] [PubMed]

111. Devi, V.G.; Rooban, B.N.; Sasikala, V.; Sahasranamam, V.; Abraham, A. Isorhamnetin-3-glucoside alleviates oxidative stress and opacification in selenite cataract in vitro. Toxicol. In Vitro 2010, 24, 1662-1669. [CrossRef] [PubMed]

112. Muhs, A.; Lyles, J.T.; Parlet, C.P.; Nelson, K.; Kavanaugh, J.S.; Horswill, A.R.; Quave, C.L. Virulence inhibitors from Brazilian Peppertree block quorum sensing and abate dermonecrosis in skin infection models. Sci. Rep. 2017, 7, 42275. [CrossRef] [PubMed]

113. Khan, M.F.; Tang, H.; Lyles, J.T.; Pineau, R.; Mashwani, Z.R.; Quave, C.L. Antibacterial properties of medicinal plants from Pakistan against multidrug-resistant ESKAPE pathogens. Front. Pharmacol. 2018, 9, 815. [CrossRef] [PubMed] 
114. Liu, K.; Abdullah, A.A.; Huang, M.; Nishioka, T.; Altaf-Ul-Amin, M.; Kanaya, S. Novel approach to classify plants based on metabolite-content similarity. BioMed Res. Int. 2017, 2017, 5293729. [CrossRef] [PubMed]

115. Bennett, B.C. Doctrine of Signatures: An explanation of medicinal plant discovery or dissemination of knowledge? Econ. Bot. 2007, 61, 246-255. [CrossRef]

(C) 2018 by the authors. Licensee MDPI, Basel, Switzerland. This article is an open access article distributed under the terms and conditions of the Creative Commons Attribution (CC BY) license (http://creativecommons.org/licenses/by/4.0/). 